
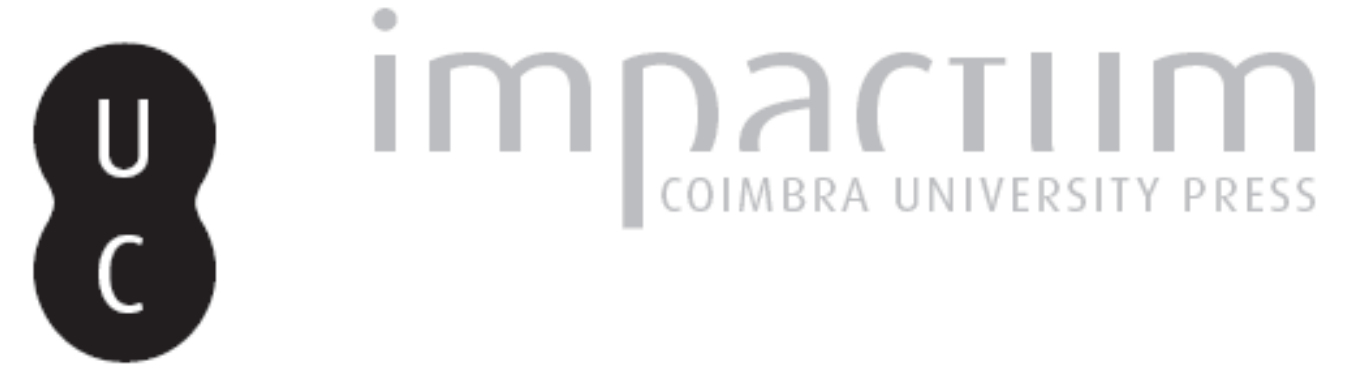

\title{
Os polos de captação de água de Conimbriga
}
Autor(es):
Neto, Celso José dos santos; Pessoa, Miguel; Madeira, José Luís; Tröger, Uwe; Sacramento, Manuel Mário dos Santos

Publicado por: Imprensa da Universidade de Coimbra

URL persistente:

URI:http://hdl.handle.net/10316.2/45483

DOI:

DOI:https://dx.doi.org/10.14195/1647-8657_32_33_9

Accessed : $\quad$ 26-Apr-2023 12:10:37

A navegação consulta e descarregamento dos títulos inseridos nas Bibliotecas Digitais UC Digitalis, UC Pombalina e UC Impactum, pressupõem a aceitação plena e sem reservas dos Termos e Condições de Uso destas Bibliotecas Digitais, disponíveis em https://digitalis.uc.pt/pt-pt/termos.

Conforme exposto nos referidos Termos e Condições de Uso, o descarregamento de títulos de acesso restrito requer uma licença válida de autorização devendo o utilizador aceder ao(s) documento(s) a partir de um endereço de IP da instituição detentora da supramencionada licença.

Ao utilizador é apenas permitido o descarregamento para uso pessoal, pelo que o emprego do(s) título(s) descarregado(s) para outro fim, designadamente comercial, carece de autorização do respetivo autor ou editor da obra.

Na medida em que todas as obras da UC Digitalis se encontram protegidas pelo Código do Direito de Autor e Direitos Conexos e demais legislação aplicável, toda a cópia, parcial ou total, deste documento, nos casos em que é legalmente admitida, deverá conter ou fazer-se acompanhar por este aviso.

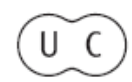




\section{UNIVERSIDADE DE COIMBRA \\ FACULDADE DE LETRAS}

\section{CONIMBRIGA}

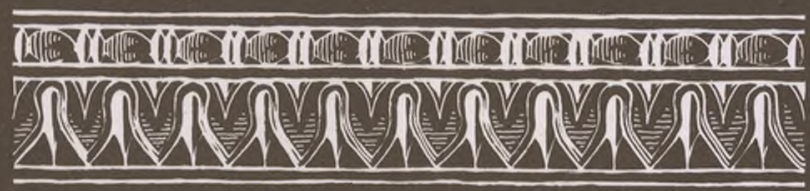

VOLUMES XXXII-XXXIII-1993/94 


\title{
Celso José dos Santos Neto
}

Hidrogeólogo da Technische Universität Berlin

\section{Miguel Pessoa}

Arqueólogo/Museólogo do Museu Monográfico de Conimbriga

\section{José Luís MADEIRA}

Técnico Superior do Instituto de Arqueologia da Faculdade de Letras de Coimbra

\section{UWE TRÖGER}

Geólogo da Technische Universität Berlin

\section{Manuel Mário dos Santos Sacramento}

Espeleólogo do Grupo de Arqueologia e Espeleología de Pombal

\author{
OS POLOS DE CAPTAÇÃO DE ÁGUA DE CONIMBRIGA \\ «Conimbriga» XXXII-XXXIII (1993-1994), p. 171-179
}

RESUMO: Conimbriga, no mais remoto tempo da sua ocupação humana (Séc. X a.

C.), terá sido preferida por ser um local alto, plano, protegido e seguro (konion - eminência pedregosa; brik - elevação). Depois o aproveitamento destas condições naturais levou à sua fortificação.

Mas outra razão, não de menor importância, que terá pesado na escolha deste local e que a toponímia não lembra foi seguramente a da presença de água em abundância no vale a norte do planalto, na actual Condeixa-a-Velha. Aí se localizam cinco nascentes.

A cidade de Conimbriga do Alto Império (Séc. I a. C.) exigiu um maior e melhor abastecimento de água para os seus habitantes. O caudal das nascentes do vale a norte deixou de ser suficiente e a sua localização desadequada para a ligação directa a casas, fontes e termas. Foi então construído o aqueduto que captava água na maior nascente de Alcabideque.

$\mathrm{O}$ aqueduto romano não aguentou muitos séculos de uso e as invasões suévicas do Século V ter-lhe-ão provocado danos irreparáveis.

Isto terá levado a que os habitantes tivessem voltado a abastecer-se nas pequenas nascentes das imediações. Esta mudança não será estranha a 
que o referido vale a norte se tenha vindo a tornar no berço da actual Condeixa-a-Velha, cujo núcleo urbano antigo, de plano peculiar com características medievais, é encimado pelo conjunto arciprestal formado pela igreja, cemitério e casa do arcipreste, (CORREIA, 1953).

Hoje, no entanto, em nenhuma das nascentes citadas brota água potável.

RÉSUMÉ: Dans les temps les plus reculés de son occupation humaine ( $\mathrm{X}^{\mathrm{ème}}$ siècle av. J.C.), Conimbriga a été préférée parce qu'elle un lieu défendable, plat et sûr (konion-éminence rocheuse, ÆnUélevation). En profitant de ces conditions naturelles, on l'a fortifiée.

Une autre raison, également très importante, dans le choix de ce site, que la toponymie ne rappelle pas, aura été sûrement la présence de Peau en abondance dans la vallée nord du plateau, aujourd'hui Condeixa-a- Velha. On y trouve cinq sources naturelles.

Plus tard, la ville de Conimbriga, dans le Haut Empire (Ier siècle av. J.C.), a exigé une plus grande quantité d'eau pour le confort de ses habitants. Le débit des sources naturelles de la vallée nord n'était plus suffisant et leur localisation inadéquate pour la liaison directe aux habitations, thermes et fontaines. On a alors décidé de construire un aqueduc afin de capter les eaux de la source la plus importante d'Alcabideque. L'aqueduc romain n'a pas supporté des siècles d'utilisation et les invasions suèves du Vème siècle ont causé des dommages irréparables.

Cet évènement va changer le comportement de la population restante qui va réutiliser les anciennes sources. Ce changement va créer de nouvelles conditions de vie à l'époque médiévale et la vallée nord deviendra le berceau de Condeixa-a-Velha. Ce noyau urbain ancien est dominé par l'ensemble archipresbytéral formé par l'église, le cimetière et la maison de l'archiprêtre (CORREIA, 1953).

Aujourd'hui, malheureusement, l'eau des sources n'est plus potable. 


\section{OS POLOS DE CAPTAÇÃO DE ÁGUA DE CONIMBRIGA}

\section{Introdução}

Conimbriga, habitada desde o Bronze Final (séc X a.C.), era então abastecida por águas das nascentes cársicas das imediações.

Muitos séculos depois, no tempo do Imperador Augusto (séc. I a.C.), o crescimento populacional exigiu obras de captação de água de nascentes mais distantes. A solução veio com a construção do aqueduto que ligava a nascente de Alcabideque até às Termas do Sul em Conimbriga (est. II).

A população da cidade é difícil de calcular, mas a partir do caudal do aqueduto e dos gastos médios de água por pessoa poderá ser estimada, talvez com algum excesso, entre os 10.000 e os 15.000 habitantes no auge da ocupação romana (GOLVIN em AlARCÃo, 1977). Foi nessa época um dos centros culturais e económicos da Lusitânia.

\section{As Fontes e os Aquedutos de Condeixa-a-Velha}

A oeste de Condeixa-a-Velha, já nas proximidades do canhão flúvio-cársico de Conimbriga, encontram-se algumas nascentes, aquedutos, tanques e fontanários utilizados pelos habitantes deste vale, para seu abastecimento, em diferentes épocas.

Se admitirmos que, nos últimos séculos antes da era cristã, o regime hídrico era aproximadamente igual ao que observamos nos nossos dias, o caudal de verão destas nascentes terá rondado $11 / \mathrm{s}$ (valor encontrado nos verões de 1992 e 1993). 
Algumas obras foram necessárias para evitar desperdícios e, mais importante, para preservar a qualidade das águas. Ao todo são 2 aquedutos, 5 tanques e 4 pias, que contruídos numa pequena área, podem transportar e armazenar parte das águas nascidas ao longo das encostas do planalto que sustenta as ruínas da antiga cidade romana (Foto 3). Uma outra importante obra hidráulica que devemos destacar é o aterramento parcial do vale e a criação de uma conduta subterrânea encaixada na drenagem, com cerca de uma centena de metros. Esta obra fez com que a ribeira que aí existia "desaparecesse" por debaixo das terras, ainda hoje cultivadas.

Para galgar a linha de água de pendente suave deste vale norte foram necessárias construções específicas das quais se conhece desde já, sob o viaduto, um grande colector onde ligam os sectores de rede de esgotos e drenagem de águas pluviais (OLEIRO, 1992). As águas do Rio dos Mouros (Foto 2) na vertente sul do planalto não eram susceptíveis de aproveitamento mesmo com construções hidráulicas, dada a existência de um declive topográfico bastante acentuado (aproximadamente 50 metros de desnível) e caudal intermitente.

Voltando ao vale norte, além da existência de um tanque de forma arredondada (est. VI/NC24) com aproximadamente 43 metros quadrados, outros tanques de menores dimensões e de formato rectangular, todos de data incerta, podem ainda ser encontrados nas proximidades do actual fontanário (Est. V/NC3), restaurado em 1925 (interior do aqueduto) e 1939 (lavadouro) pela Câmara Municipal de Condeixa.

Dois aquedutos foram aí construídos em época que se nos afigura difícil identificar (est. III). Recebiam água do maciço rochoso. Com ela as populações supriam as necessidades. Um dos aquedutos (NC28), de aproximadamente 15 metros de comprimento por $50 \mathrm{~cm}$ de largura e $90 \mathrm{~cm}$ de altura, desaguava num pequeno tanque (opus Signinum ?) revestido com cimento há duas décadas e construído em tempos recuados para armazenar o excesso de água que poderia ser utilizada em verões quentes e secos. Um segundo aqueduto (NC3), construído para captar águas nascidas nos tufos calcários (est. IV), agora mascarado pelos restauros praticados pela Câmara Municipal, apresenta características singulares, com uma conduta de 11,60 metros de comprimento que traz a água dividida em duas canaletas distintas.

A canaleta menor apresenta largura e profundidade média de aproximadamente $10 \mathrm{~cm}$, enquanto que a canaleta maior possui uma largura de $15 \mathrm{~cm}$ e profundidade de $10 \mathrm{~cm}$ (est. IV). Sabendo que o 
caudal encontrado na nascente NC3A é muito maior que em NC3B, é correcto afirmar que as águas não se misturam, visto que, se admitirmos um caudal de $10 \mathrm{l} / \mathrm{s}$ para as águas provenientes da canaleta maior a uma velocidade de $1 \mathrm{~m} / \mathrm{s}$, o que só poderia acontecer em invernos muito rigorosos, a altura máxima que a água poderá alcançar neste troço é de $7 \mathrm{~cm}$, o que nos garante a separação entre as águas. No entanto, esta separação poderá indicar-nos que estamos perante águas de diferentes composições químicas, pois aparentemente não haveria outra razão para se fazer obra hidráulica tão singular. A mistura entre as águas das duas nascentes (NC3A e NC3B3) terá ocorrido após as obras de restauro em 1939.

A seguir ao fontanário, bordando o espaço da antiga via romana (PESSOA, 1991), encontramos a nascente NC21 (est. V) que desagua em 4 pias alinhadas e em ligação com um tanque de rega de aproximadamente $20 \mathrm{~m}^{2}$ (T2) o qual armazena estas águas tufo/areníticas e também as das nascentes NC3. Esta água circula depois do tanque numa canaleta a céu aberto com cerca de 250 metros de comprimento irrigando a parte inferior do vale.

NC27 é uma pequena nascente que assinalámos tendo em conta que o seu caudal, apesar de reduzido, não seca no Verão.

A importância destas obras é mais significativa quando nos leva a concluir que as populações podiam distinguir as características químicas das águas sem que possuissem um elevado conhecimento químico ou hidrogeológico. Hoje, com algumas análises químicas, podemos confirmar que as águas provenientes dos tufos/arenitos possuem águas com características que vão de excelente a boa para o consumo humano, como demonstrado pelos Parâmetros de Classificação de Uso Doméstico (quadro 1). Porém, as águas vindas dos tufos apresentam uma classificação no máximo boa para todos os itens, mostrando, no entanto, as análises químicas contaminação em nitrato.

Para o Parâmetro de Classificação de Uso Agrícola (tabela 1) as águas tufo/areníticas são classificáveis como boas enquanto que as dos tufos são apenas admissíveis. Porém, neste caso a utilização dessas águas na agricultura não causaria maiores problemas para a saúde humana, podendo ocasionar no máximo o empobrecimento mais acelerado do solo caso a utilização deste fosse feita de uma maneira irracional. 


\begin{tabular}{|c|c|c|c|}
\hline \multicolumn{4}{|c|}{ Parâmetro de Classificação (Uso Doméstico) } \\
\hline \multirow[t]{2}{*}{ Parâmetros } & \multicolumn{3}{|c|}{ Água } \\
\hline & Excelentes & Boas & Más \\
\hline $\begin{array}{c}\text { Resíduo Seco }(\mathrm{mg} / 1) \\
\text { Dureza }\left({ }^{\circ} \mathrm{d}\right) \\
\text { Clorestos }(\mathrm{mg} / 1)\end{array}$ & $\begin{array}{l}<500 \\
<8 \\
<50\end{array}$ & $\begin{array}{l}500-1000 \\
8-25 \\
50-150\end{array}$ & $\begin{array}{l}>1000 \\
>25 \\
>150\end{array}$ \\
\hline \multicolumn{4}{|c|}{ Classificação das Águas } \\
\hline $\begin{array}{c}\text { Resíduo Seco }(\mathrm{mg} / 1) \\
\text { Dureza }\left({ }^{\circ} \mathrm{d}\right) \\
\text { Clorestos }(\mathrm{mg} / 1)\end{array}$ & $\begin{array}{l}\mathrm{NC}=1 / \mathrm{NC} 21 \\
/ \\
\mathrm{NCO} 1 / \mathrm{NC} 21\end{array}$ & $\begin{array}{c}\mathrm{NC03} \\
\mathrm{NCOl} / \mathrm{NC} 03 / \mathrm{NC} 21 \\
\mathrm{NC} 03\end{array}$ & $\begin{array}{l}1 \\
1 \\
1\end{array}$ \\
\hline
\end{tabular}

Quadro 1: Parâmetros de Classificação de Uso Doméstico

Fica então claro que os primeiros habitantes desta área usufruíam dessas águas nascidas nas encostas do Canhão de Conimbriga. Porém, dado o crescimento populacional e a necessidade de uma maior protecção e conforto dos seus habitantes, novas fontes de água foram canalizadas e aproveitadas no abastecimento.

A cidade do Alto Império Romano exigiu mais quantidade de água do que o povoado proto-histórico. O caudal das nascentes da actual Condeixa-a-Velha deixou então de ser suficiente.

A construção de um aqueduto em ligação a casas, fontes e termas, suprindo todas as necessidades da cidade, era uma solução imprescindível.

\section{O Aqueduto Augustano}

Com 3.443,31 metros de comprimento, o aqueduto foi construído no tempo de Augusto, e captava a água da nascente de Alcabideque. Segundo os cálculos de J. C. Golvin (ALARCÃo, 1977), na época augustana, o débito máximo que comportava o aqueduto era de 217 1/s, decaindo com o tempo para $144 \mathrm{1} / \mathrm{s}$ na época Claudiana e $66 \mathrm{1} / \mathrm{s}$ entre os séculos III e IV, fenómeno este devido às incrustações de calcário que diminuíram a abertura do orifício de entrada. 


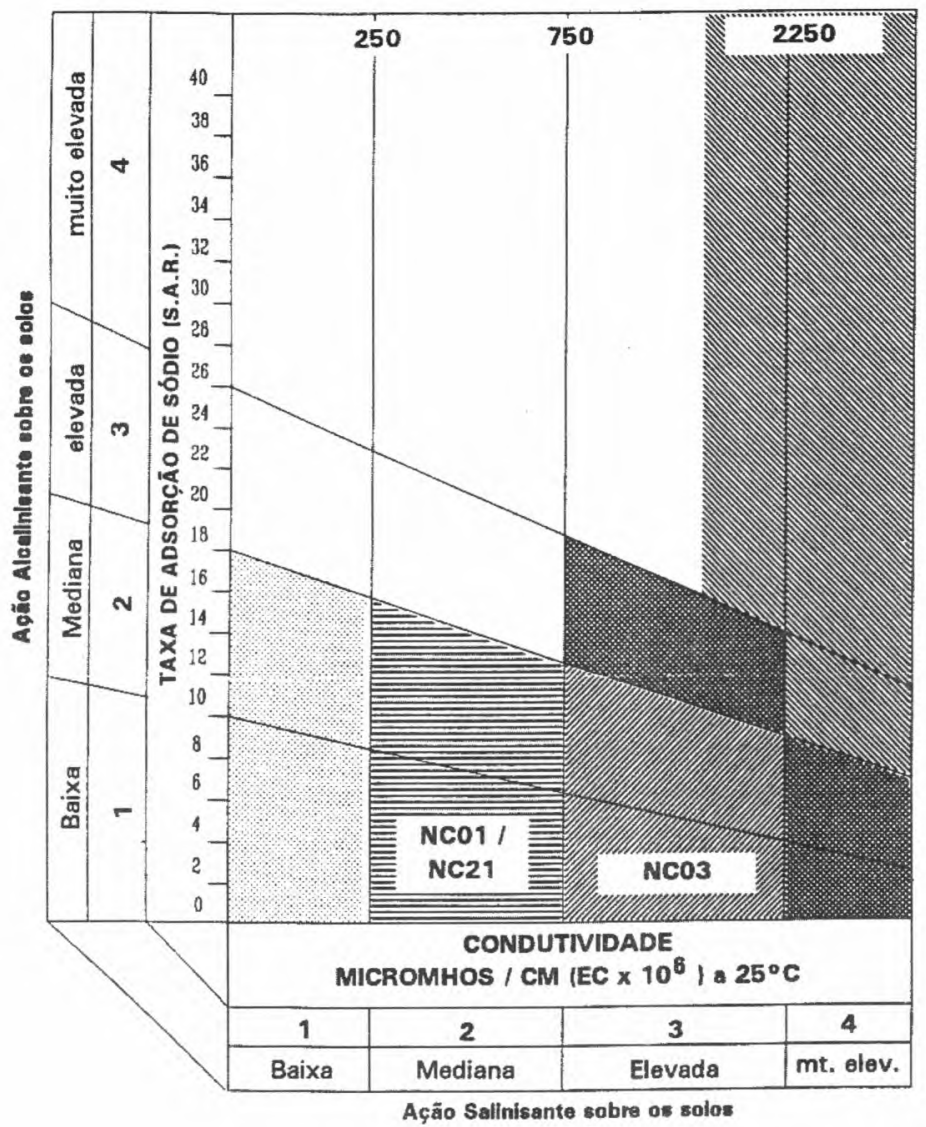

Principais Classes de Águas Ocorrentes

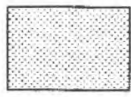

Excelente

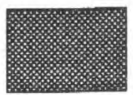

Mediocre

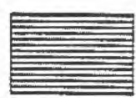

Boa

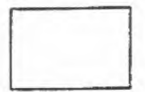

Má - R. S. $<1$

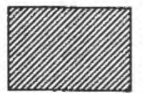

Admissivel

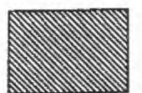

Má - R. S. > 1

TABela 1 - Parâmetro de Classificação de Uso Agrícola

Conimbriga, 32-33 (1993-1994), 171-179 
Mesmo neste último período, a água era suficiente para abastecer uma população de 19.000 pessoas. Como Conimbriga não devia possuir mais do que 10.000 a 15.000 habitantes no período de maior crescimento, somos levados a discordar de Golvin (op. cit. - p. 60) quando afirma que "A redução a $5.700 \mathrm{~m}^{3} /$ dia pode representar uma situação crítica no século IV, ocasionado pela expansão demográfica natural e a multiplicação dos usos industriais."

Um facto importante a ser destacado é o do caudal medido na nascente de Alcabideque. A média observada nos invernos dos últimos anos é de 713,4 1/s, e nos verões de 116,3 1/s. Admitindo que esses valores sejam aproximadamente iguais aos verificados nos primeiros séculos de nossa era, e que o aqueduto comportava no máximo um caudal de 217 1/s como foi demonstrado por Golvin, é possível concluir que, nos invernos, grande parte do excedente de água que nascia em Alcabideque era destinada à agricultura ou armazenado em tanques localizados próximo da nascente. Nos verões, mesmo com a diminuição do caudal, a água ainda nascia com fartura, sendo uma parte canalizada para Conimbriga e a outra utilizada para suprir as necessidades dos camponeses. A existência de comportas laterais ao longo do percurso terrestre da conduta romana leva-nos a supor o aproveitamento duma parte deste caudal na agricultura.

Um outro factor que deve ter sido levado em consideração aquando da construção do aqueduto foi o da qualidade da água explorada. Parece-nos conveniente afirmar que os antigos povos tinham conhecimento da qualidade da água consumida, facto que já foi levantado anteriormente. De facto, a água que nasce em Alcabideque é calcária e consequentemente dura; porém, de acordo com os Parâmetros de Classificação tanto para Uso Doméstico como para Uso Agrícola pode ser classificada como de excelente a boa.

\section{Conclusão}

- A povoação que deu origem à cidade de Conimbriga abastecia-se das águas das nascentes cársicas encontradas no vale formado pelo canhão flúvio-cársico.

- A conduta subterrânea encaixada nas drenagens ao longo do vale de Condeixa-a-Velha, a norte do planalto de Conimbriga, faz parte de uma grande obra hidráulica ligada à retenção e cir- 
culação das águas pluviais e domésticas, cuja datação seria do maior interesse tentar provar arqueológicamente.

- As águas das nascentes de Alcabideque e dos tufo/arenitos de Condeixa-a-Velha apresentam qualidade boa a excelente, tanto para consumo humano como para uso agrícola, o mesmo não se podendo dizer da água que nasce nos tufos das proximidades de Condeixa-a-Velha, a qual apresentava elevado grau de contaminação em nitrato aquando da realização das análises.

\section{BIBLIOGRAFIA}

alarcão, J.; Etienne, R.; Golvin, J.; Schreyeck, J,; Monturet, R.; Tavares, A. (1977) - Fouilles de Conimbriga - L'Architecture pp. 5 1-64.

Correia, Vergilio; Gonçalves, A. Nogueira (1953), Inventário Artístico de Portugal, Distrito de Coimbra, 4, Lisboa.

Costa, F. E.; Amaral Brites, J. A. T. \& Dores Pedrosa, M. Y. N. (1981) "Contribuição para o conhecimento hidrogeológico das águas subterrâneas do Ocidente Algarvio" - Separata do Tomo 67, fase. 1, das Comunicações dos Serviços Geológicos de Portugal. Lisboa p. 99-118.

Hölting, B. (1989) - "Hidrogeologie: Einführung in die allgemeine und angewandte Hydrogeologie", Stuttgart.

Neto, C.; Pessoa, M; Truger, U.; Sacramento, M. (1993) - "As feições cársicas encontradas nas proximidades de Conimbriga e os tufos de Condeixa: aspectos hidrogeológicos, geomorfológicos e espeleogenéticos", 4. ${ }^{\text {a }}$ Reunião do Quaternário Ibérico, Universidade de Coimbra.

Oleiro, J. M. B. (1992) - Casa dos Repuxos. Conimbriga (Corpus dos Mosaicos Romanos de Portugal. Conventus Scallabitanus), Conimbriga.

Pessoa, M.; Madeira, J. L.; Ferreira, D. (1991) - A Muralha Augustana de Conimbriga, Condeixa-a-Velha. Elementos de estudo, Condeixa.

As análises bacteriológicas realizadas pelo Centro de Saúde de Condeixa (Equipa de Serviço Sanitário) mostram que as águas das nascentes referidas estão impróprias para consumo sobretudo nos meses de Verão.

Agradecemos a colaboração do Prof. Doutor Jorge de Alarcão do Instituto de Arqueologia de Coimbra, João Paulo Domingues do GAEP de Pombal, Nuno Redinha de Condeixa-a-Nova, Miguel Bandeira Pessoa do Núcleo de Espeleología de Condeixa (N.E.C.), pintor João Pocinho, população de Condeixa-a-Velha, Dr. Manuel Moraes da Divisão de Hidrogeologia dos Serviços Geológicos de Portugal e fotógrafo António Pinto do Instituto da Juventude de Coimbra. 


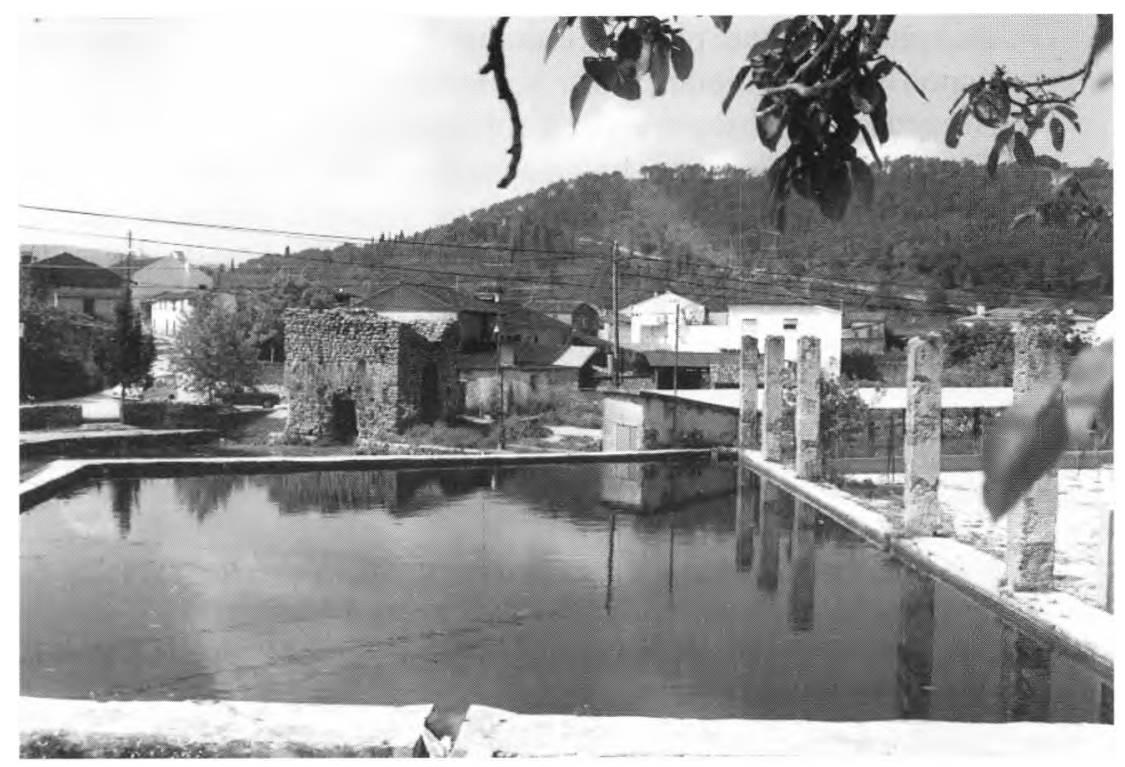

FOTO 1 - Nascente de Alcabideque. Ao fundo torre romana de captação de água. NC1 (Foto de Antonio Pinto)

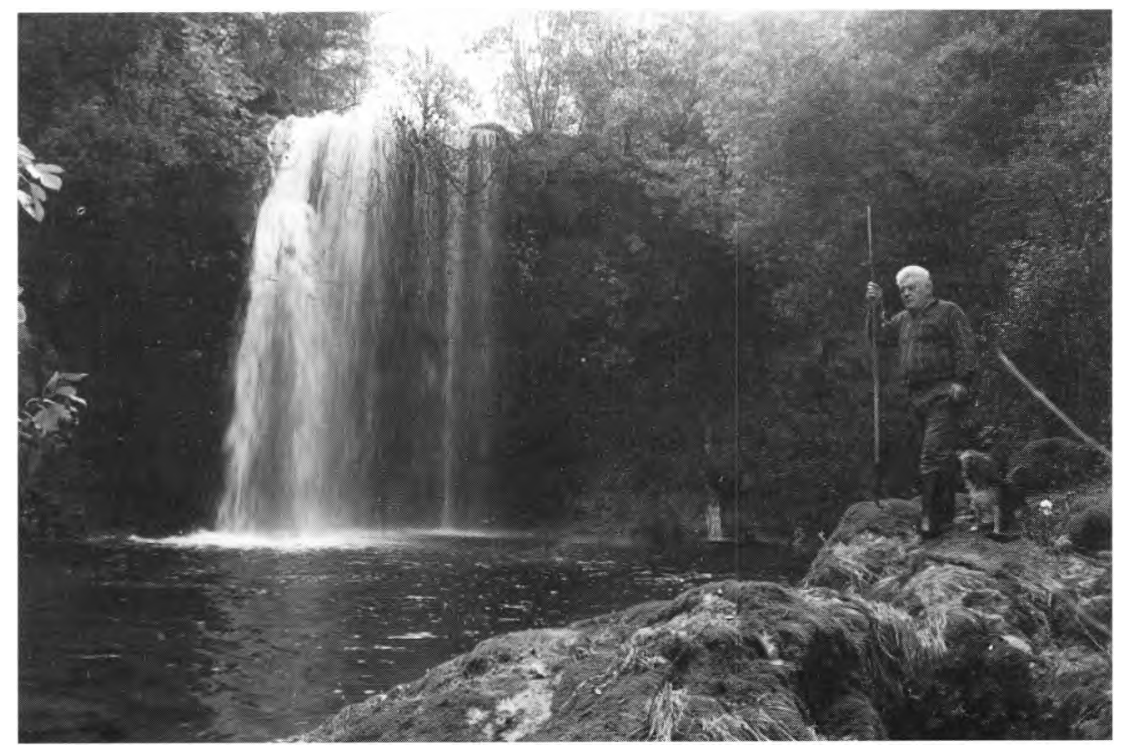

FOTO 2 - Cascata do canhão fluviocàrsico do Rio dos Mouros (Foto de Antonio Pinto) 


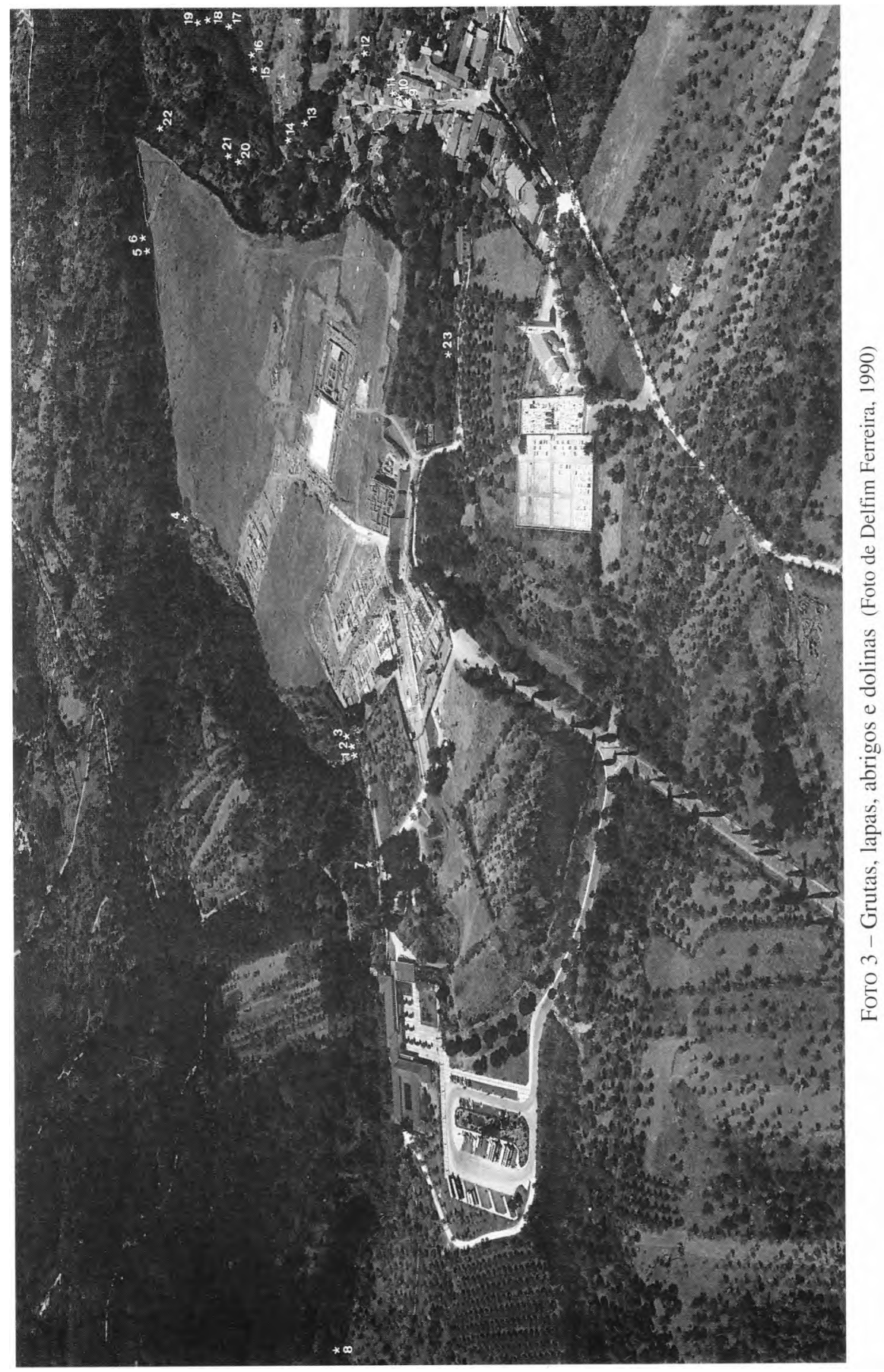


RIO DOS MOUROS

1. Gruta das Termas. 2. Abrigo Pequeno. 3. Abrigo das Aranhas 4. Dolina da Cheminé. 5. Lapa dos Jovens. 6. Gruta da Igreja dos Mouros 7. Lapa dos Loureiros. 8. Lapa da Cascata

CONDEIXA A VELHA

9. Lapa do Curral Concelho. 10. Abrigo do Justo. 11. Abrigo do Galinheiro 12. Abrigo dos Quatro Donos. 13. Abrigo da Muralha Antiga. 14. Abrigo da Eira 15. Lapa dos Outeiros. 16. Abrigo dos Outeiros. 17. Lapa dos Arenitos 18. Abrigo das Lapinhas. 19. Abrigo da Boavista. 20. Gruta da Claridade 21. Gruta dos Três Morcegos. 22. Lapa das Pombas

LEGENDA DA FOTO 3 


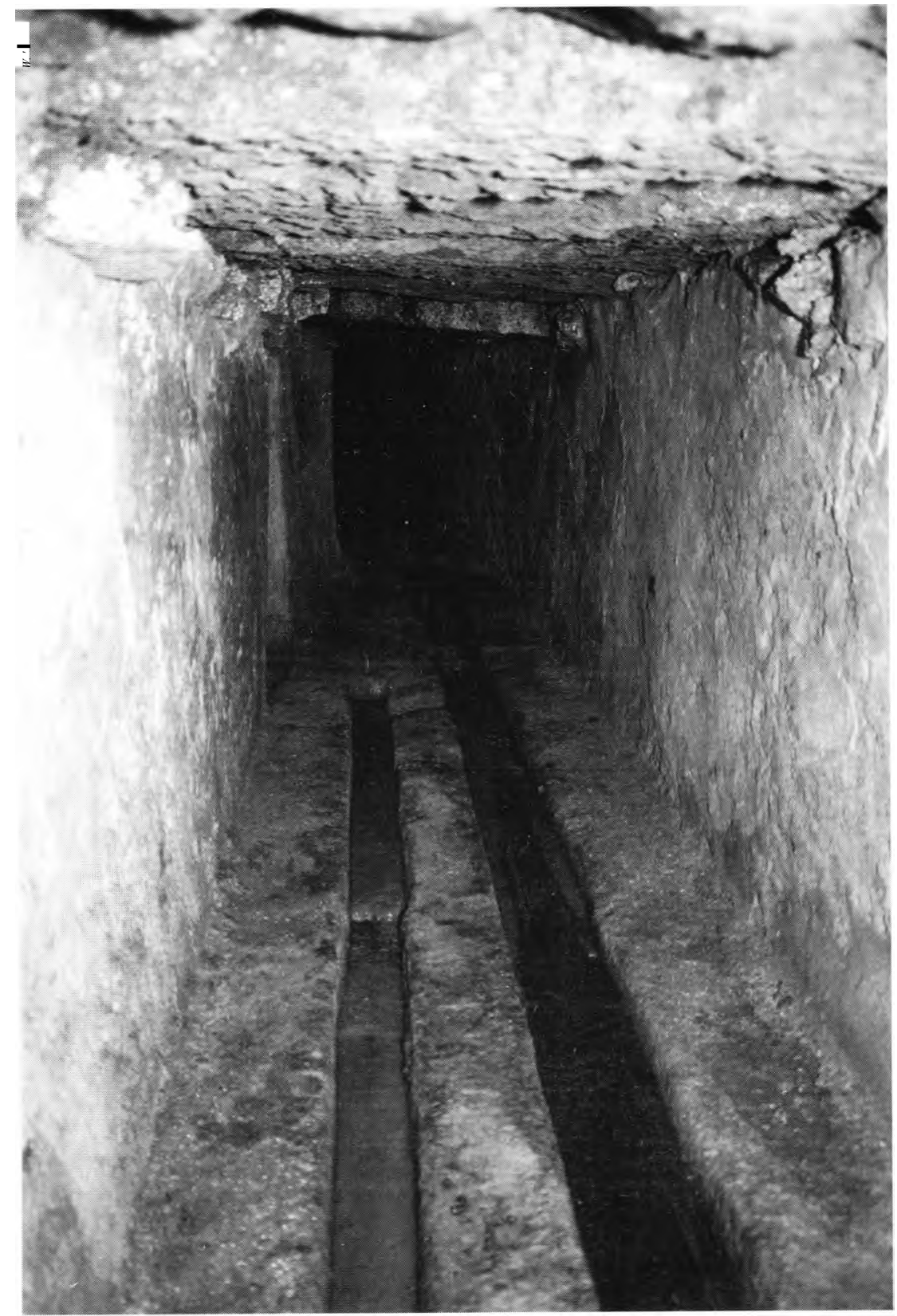

Fото 4 - Aqueduto da nascente de Condeixa-a-Velha, NC3 (Foto de Antonio Pinto) 
EST. I

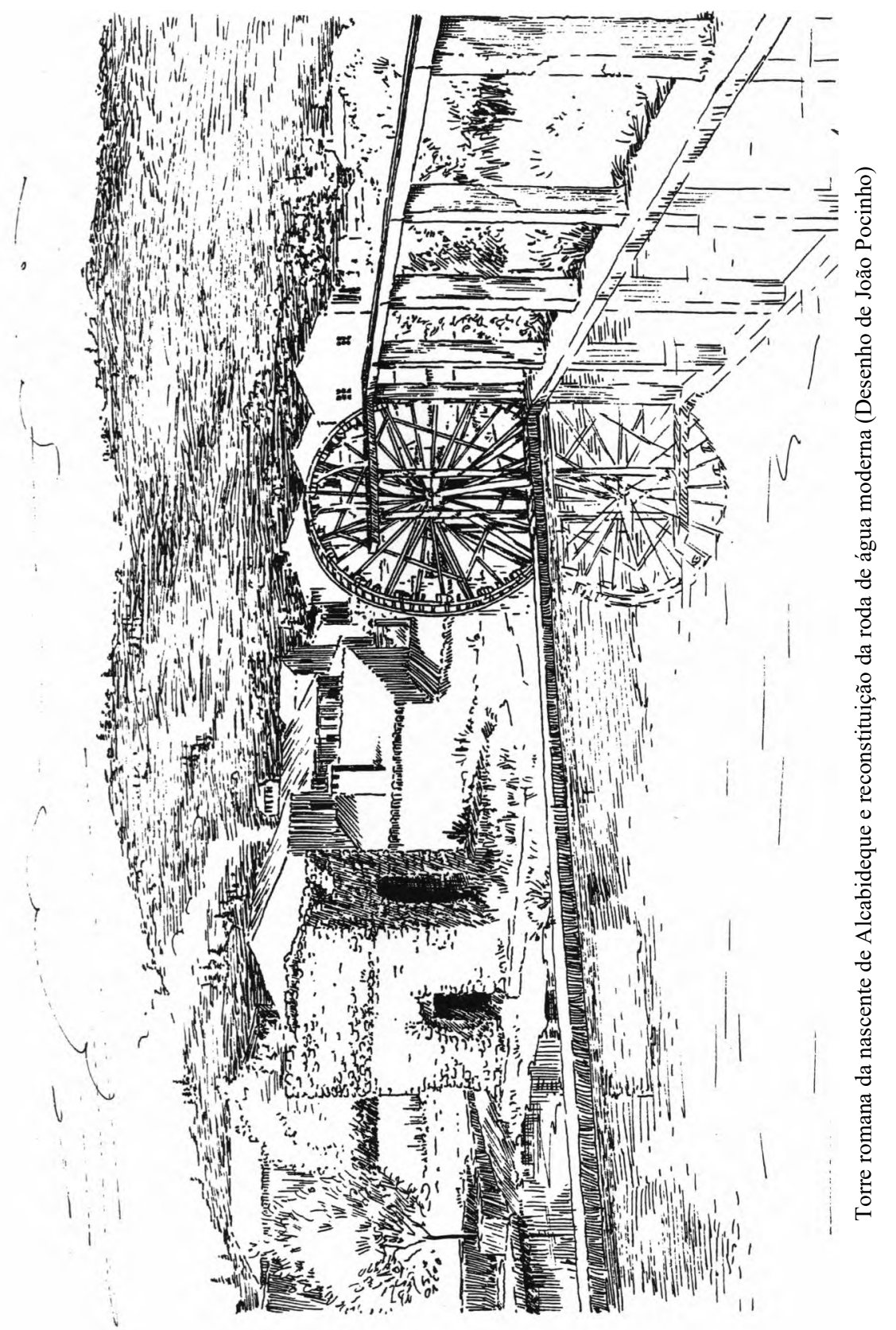


EST. II

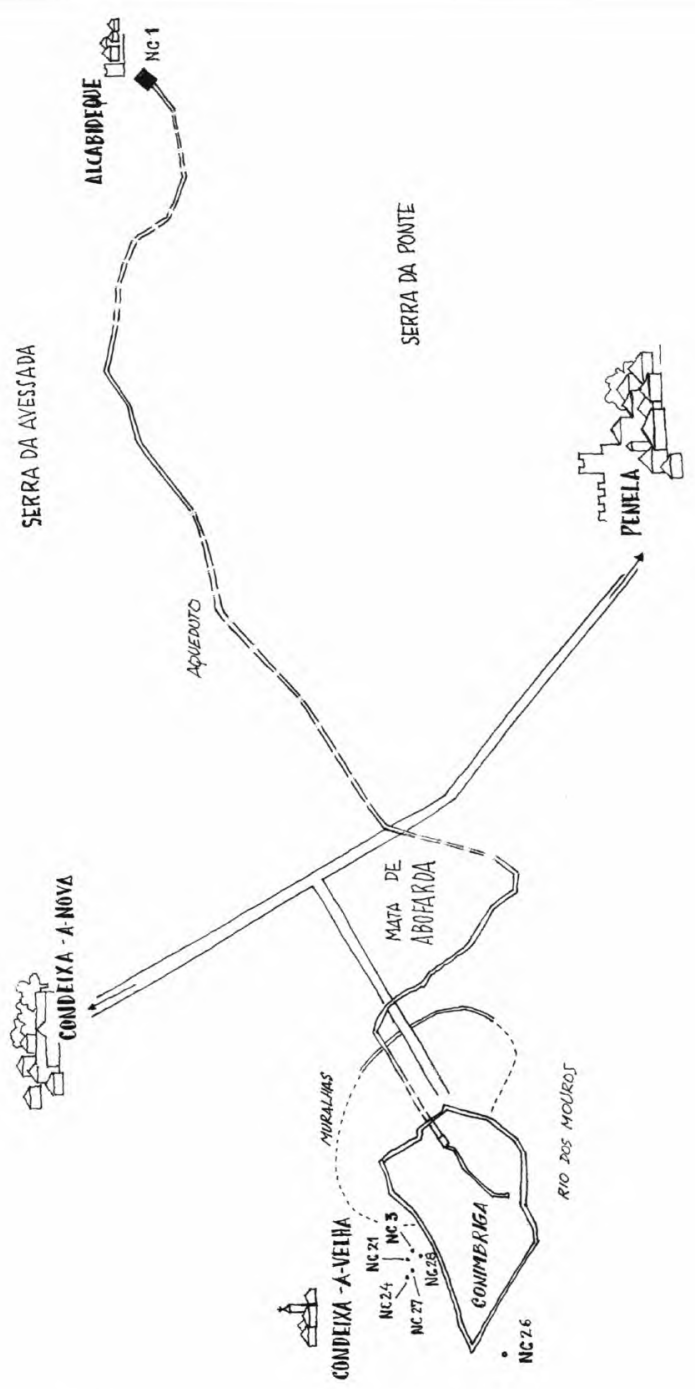

षे 
EsT. IV

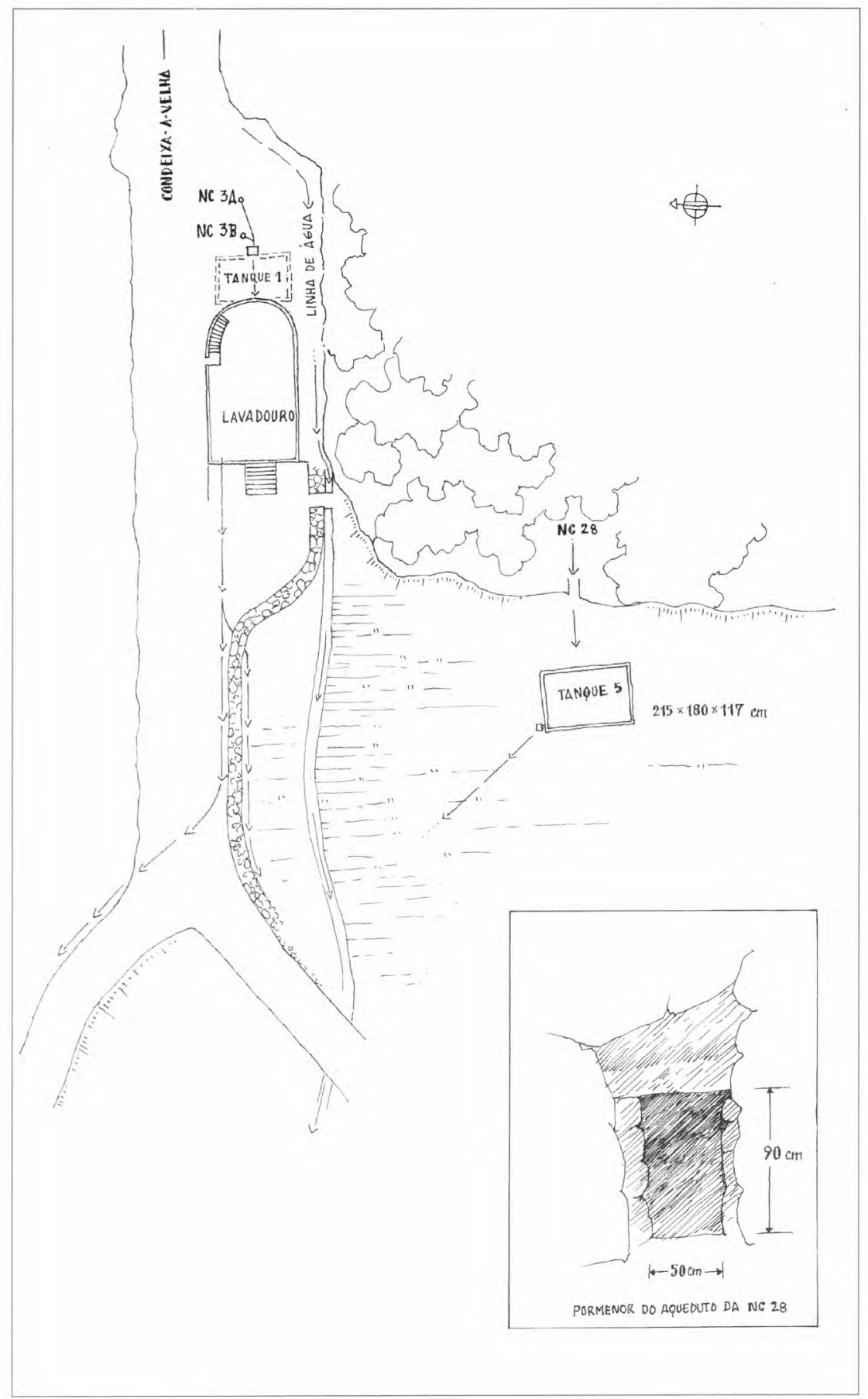




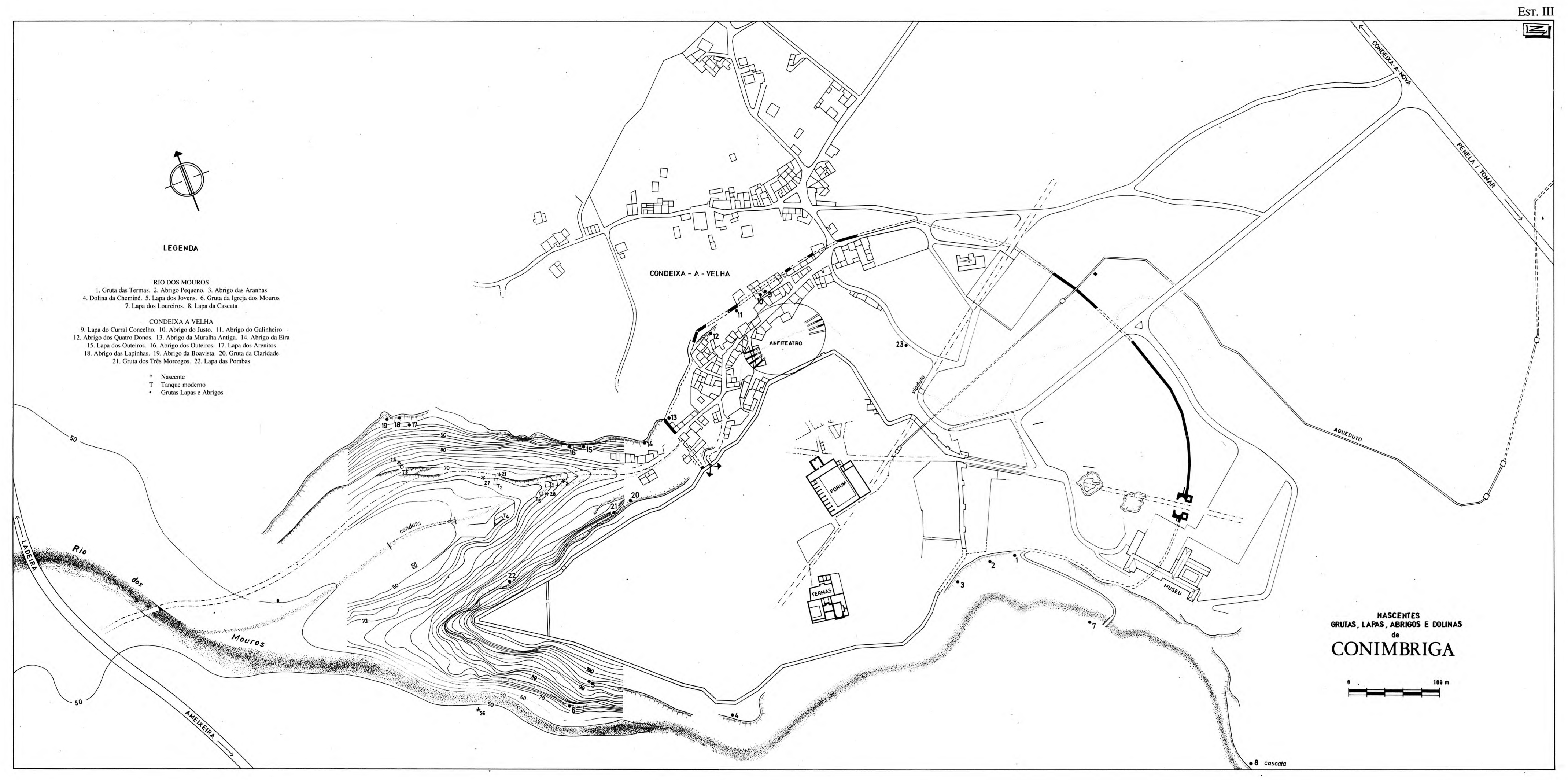


(Página deixada propositadamente em branco) 
EST. V

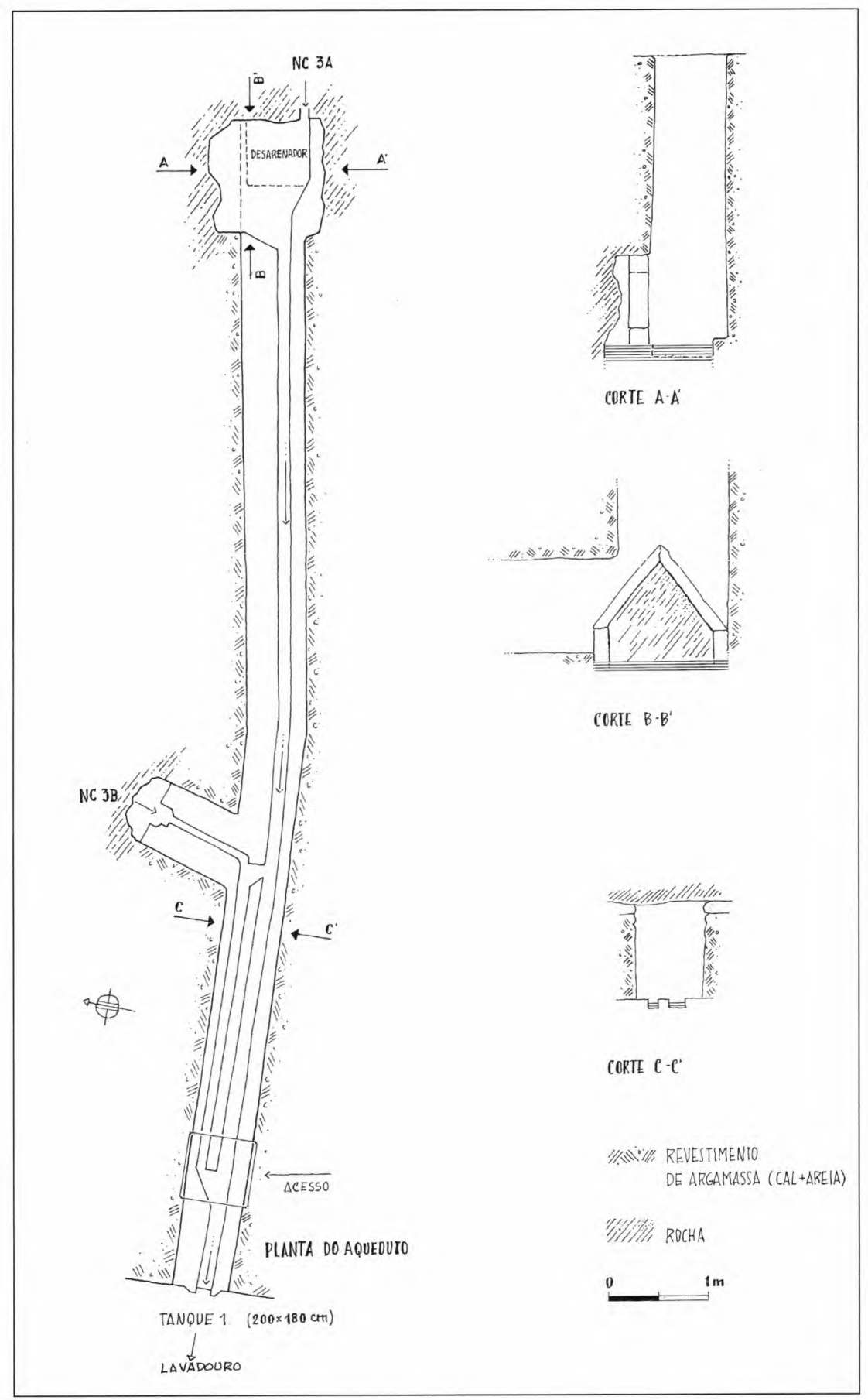


EST. VI

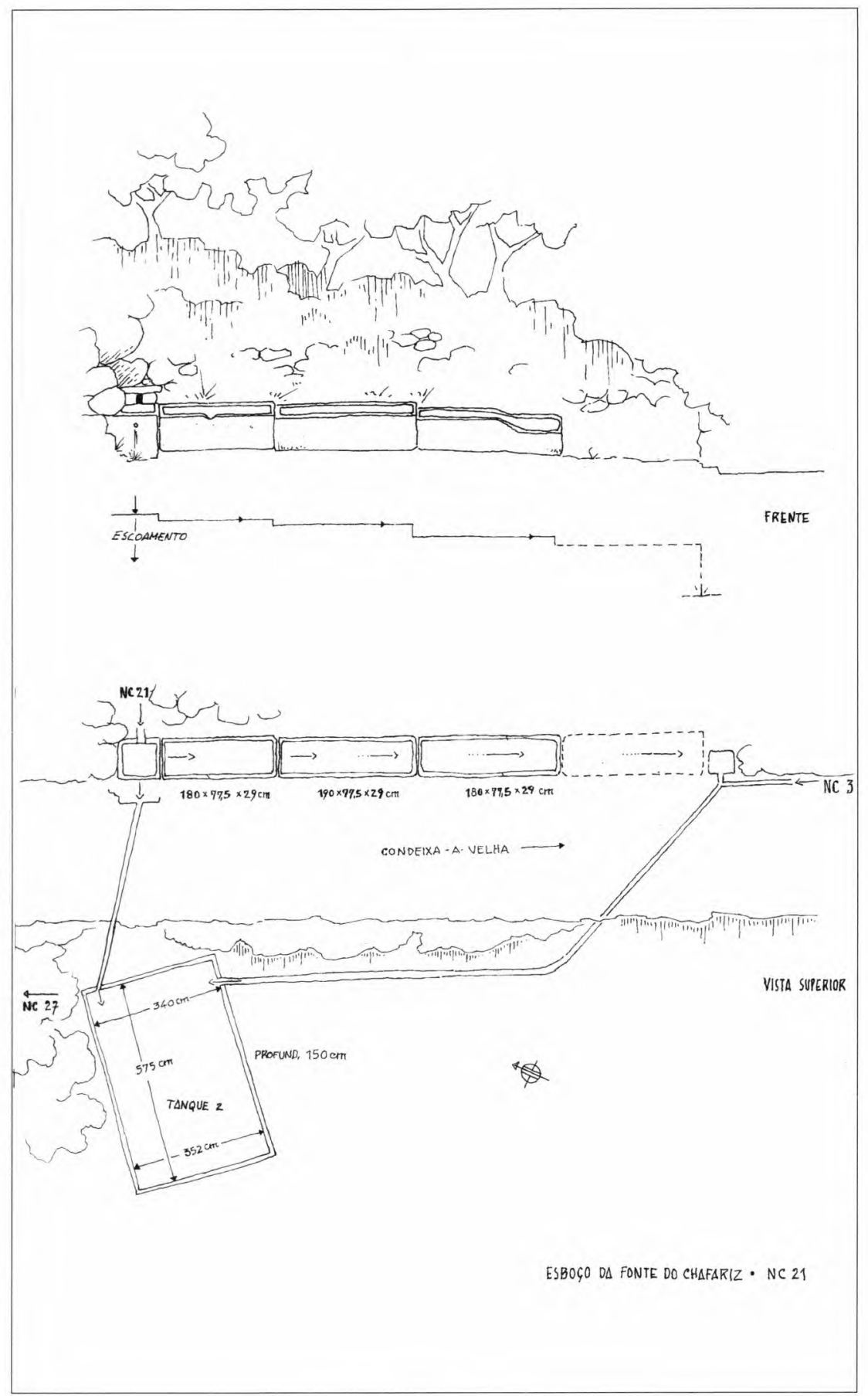


EST. VII
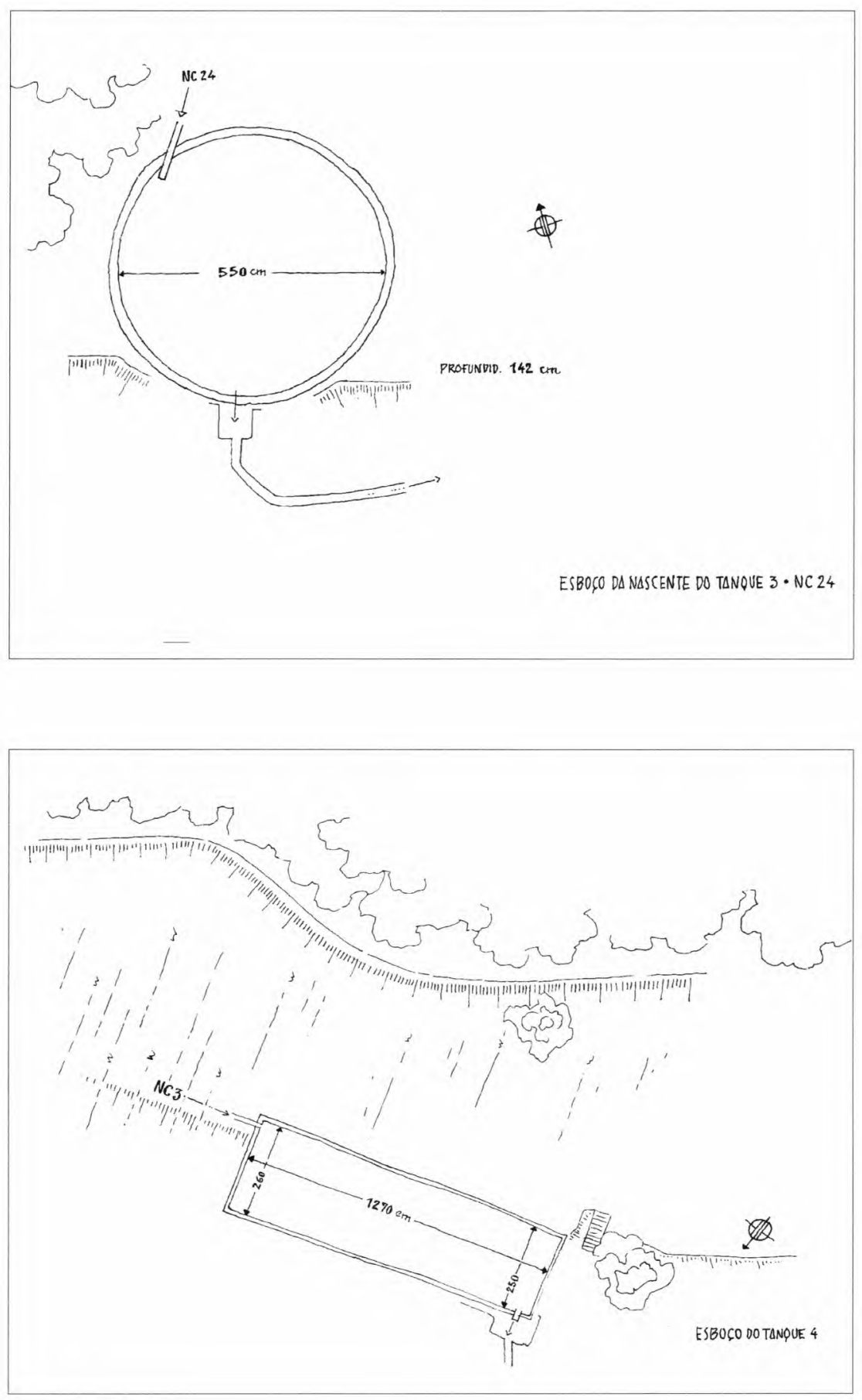